\title{
Neraca Massa, Komposisi Kimia dan Nilai Ekonomis PengolahanAgroindustri Glukomanan
}

\section{Mass Balance, Chemical Composition and Economic Value of Glucomannan Agro Industry Processing}

\author{
M F Kurnianto ${ }^{1}$, Budi Hariono ${ }^{2}$, Sri Hartatik ${ }^{3}$ \\ ${ }^{1}$ Teknologi Industri Pangan, Teknologi Pertanian, Politeknik Negeri Jember \\ ${ }^{2}$ Keteknikan Pertanian, Teknologi Pertanian, Politeknik Negeri Jember \\ ${ }^{3}$ Jurusan Agroteknologi, Fakultas Pertanian Universitas Negeri Jember \\ ${ }^{1}$ E-mail: ftnpolijedgmail.com
}

\begin{abstract}
Uber Gadung (Dioscorea Hispida dennst) is a tuber plant that can produce glucomannan. Chemically, glucomannan is a non-ionic hydrochloric polysaccharide compound, having a high molecular weight of 9.0x105gmol-1atau2.7x1051.1x106Dalton. The current problem is not done to the mass balance calculation at the end of the product being the processing base at the agroindustry level. The study consists of 3 main stages, including: (i) sampling; (ii) Product fractionation and drying; (iii) Economic extraction and calculation. The results showed that the calculation of the mass balance of treatment difference in mesh size gives the result that the larger the size (smaller particle size), resulting in less glucomannan. The fraction of glucomannan flour which passes 40-60 mesh sieve produces the highest glucomannan content compared to other particle size. The particle size treatment has significant effect on glucomannan, starch, crude fiber, water, density of kamba, viscosity, $\mathrm{pH}$, and weight percentage. The highest yield is found in 40-60 mesh flour mung, while the highest starch and crude fiber content is in the size $<100 \mathrm{mesh}$. The highest added value is obtained from the processing into glucomannan with the value of $R \mathbf{p} 650.000 / 100 \mathrm{~kg}$, as well as the profit of 86.67 percent. While the value of the lowest profits on the processing of gadung tuber into a dry chip.
\end{abstract}

Keywords : Uber Gadung, glucomannan, dry chip

\section{PENDAhUluAN}

Umbi Gadung (Dioscorea Hispida dennst) merupakan tanaman umbiumbianyangbanyakdijumpaidiwilayahIndonesia, apabila diolah oleh agroindustri dapat menghasilkan glukomanan. Secara kimia, glukomanan merupakan senyawa polisakarida hidrokoloid yang bersifat non-ionik, mempunyai bobot molekul yang tinggi yaitu $9.0 \times 10^{5} \mathrm{gmol}^{-}$ ${ }^{1}$ atau2.7 $\times 10^{5}-1.1 \times 10^{6} \mathrm{Da}($ Liuetal.2017).

Glukomanan mempunyai ikatan p-1,4 glikosidik dan monomer berupa D-glukosa dan gugus Dmanosa dengan perbandingan $1: 1.64$, dengan ikatan cabang pada atom p-1,6-gugus glukosil ( $\mathrm{Li}$ et al. 2006, dan Chua et al. 2016). Setiap 19 unit glukomanan mengandung satu gugus asetil (Liu et al. 2017). Tingkat percabangan rantai glukomanan terletak pada atomC-3 pada setiap 32 molekul glukosa(Chua et al.2016).

Glukomanan mempunyai banyak manfaat di berbagai bidang industri seperti makanan 
M F Kurnianto, Budi Hariono, Sri Hartatik. Neraca Massa, Komposisi Kimia Dan Nilai Ekonomis Pengolahan Agroindustri Glukomanan .

(shirataki dan konyaku), obat-obatan, kimia, tekstil, bioindustri (bahan biakan mikroba), dan edible film (Raharjo et al. 2017). Selain itu glukomanan juga dapat digunakan untuk mencegahkegemukan serta penyakit karena tumor (Liu et al. 2017). Glukomanan dapat digunakan untukmenurunkankolesteroldalamdarah,mengobati penyakitdiabetesmellitus, dan emulsifier ( $\mathrm{Li}$ et al. 2006 dan Chua et al. 2016). Bo et al. (2013) menyatakan bahwa apabila glukomanan dikenakan proses sulfatasi dengan asam piperidin nitrogen sulfonat dapat berfungsi sebagai senyawa anti-human immunodeficiency virus (HIV). Glukomanan mempunyai nilai ekonomis yang tinggi karena harganya mahal, sehingga berpotensi untuk menjadi salah satu produkekspor.

Masalahyangdihadapisaat iniadalahbelumdilakukan perhitungan neraca massa pada hasil akhir yaitu rendemen glukomanan dan komposisi kimia yang terkandung didalamnya dan menjadi basis pengolahan di tingkat agroindustry.

\section{METODE PENELITIAN}

Penelitian ini terdiri dari 3 tahapan utama, meliputi: (i) pengambilan sampel; (ii) fraksinasi dan pengeringan Produk; (iii) Ekstraksi dan perhitungan ekonomi.Bahan umbi gadung diambil dari Desa Tutur Kabupaten Pasuruan ditimbang sebanyak 2000 g lalu dicuci dengan air bersih.
Umbi diiris melintang menggunakan slicer dengan ketebalan 6 mm.Dilaksanakan pada bulan Maret Mei 2018.

Sampel dikeringkan dengan pengeringan matahari. Jumlah tumpukan chips tiga lapis, dan kapasitas pengeringan $2 \mathrm{~kg}$ bahan. Percobaan diakhiri setelah pengamatan selama 36 jam yang menghasilkan kadar air sampel akhir mencapai sekitar $10-12 \%$, chips yang telah kering dianalisis kadar proksimat dan mutunya. Kadar air pada akhir pengamatan yaitu 36 jam dianggap sebagai kadar air kesetimbangan karena menghasilkan kadar air yang tidak berubah dan dianalisis menggunakan eksperimental design Rancangan acak Lengkap (RAL) dengan 2 kali ulangan.

Parameter diamati meliputi kadar glukomanan (AOAC 2005), kadar air (AOAC 2005), kadar pati (AOAC 2005), kadar serat kasar (AOAC 2005), kadar lemak (AOAC 2005), viskositas (AOAC 2005), densitas kamba (AOAC 2005), pH (AOAC 2005), rendemen (Yao-Ling et al. 2016), perhitungan nilai ekonomis masing - masing hasil produk setiap proses pengolahan (Raharjo, dkk. 2017) .

\section{HASIL DAN PEMBAHASAN}

\section{Neraca Massa dan Komposisi Kimia Tepung Glukomanan}

Hasil analisis persentase rendemen disajikan dalam gambar 1 sebagai berikut :

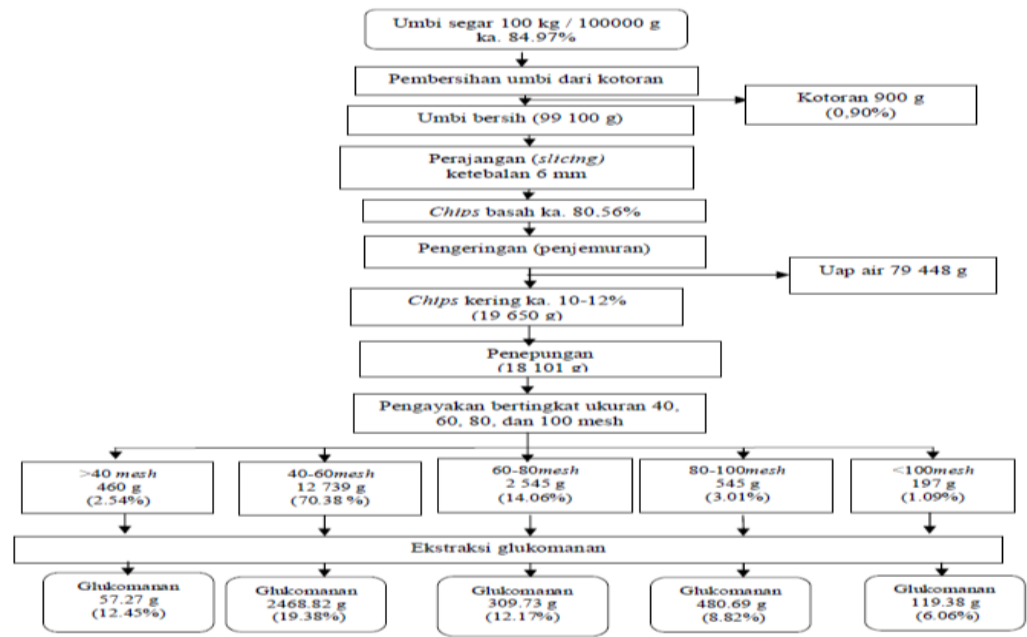

GAMBAR 1. PERHITUNGAN NERACA MASSA TEPUNG GLUKOMANAN PADA BERBAGAI TINGKAT UKURAN PENGAYAKAN (MESH) 


\begin{tabular}{|c|c|c|c|c|c|c|}
\hline neraca massa & Densita & & & & & \\
\hline perlakuanperbedaanukuran mesh (gambarl) & & $\begin{array}{c}810 \\
a\end{array}$ & $790^{\mathrm{b}}$ & $560^{\mathrm{c}}$ & $435^{\mathrm{d}}$ & $350^{\mathrm{e}}$ \\
\hline $\begin{array}{l}\text { memberikan hasil yaitu semakin besar ukuran } \\
\text { (ukuran partikel semakin kecil), menghasilkan }\end{array}$ & $\begin{array}{l}\text { kamba } \\
(\mathrm{g} / \mathrm{ml})\end{array}$ & & & & & \\
\hline glukomanan yang semakin sedikit. Fraksi tepung & & $7 \times 1$ & 15.85 & $13.22 \mathrm{x}$ & 1.415 & 0.462 \\
\hline glukomanan yang lolos ayakan 40-60 mesh & $\begin{array}{l}\text { tas } \\
\text { (cPs) }\end{array}$ & $0^{3 \mathrm{bc}}$ & $\mathrm{x} 10^{3 \mathrm{a}}$ & $10^{3 \mathrm{ab}}$ & $\mathrm{x} 10^{3 \mathrm{c}}$ & $\mathrm{x} 10^{3 \mathrm{~d}}$ \\
\hline $\begin{array}{l}\text { menghasilkan kandungan glukomanan paling tinggi } \\
\text { dibandingkan dengan ukuran partikel yang lain. }\end{array}$ & $\mathrm{pH}$ & $\begin{array}{r}5 . \\
96^{\mathrm{c}}\end{array}$ & $6.01^{\mathrm{bc}}$ & $6.02^{\mathrm{c}}$ & $6.08^{\mathrm{ab}}$ & $6.13^{\mathrm{a}}$ \\
\hline $\begin{array}{l}\text { Tepung yang memiliki ukuran dibawah 60mesh } \\
\text { menghasilkan kadar glukomanan lebih sedikit. Hal } \\
\text { ini menggambarkan bahwa tepung yang memiliki } \\
\text { ukuran nartikel semakin besar kecuali }(<40 \text { mesh) }\end{array}$ & $\begin{array}{l}\text { Persent } \\
\text { ase } \\
\text { bobot( } \\
\%)\end{array}$ & $54^{c}$ & $\begin{array}{c}70.38 \\
\mathrm{a}\end{array}$ & $14.06^{\mathrm{b}}$ & $3.01^{\mathrm{c}}$ & $1.09^{\mathrm{c}}$ \\
\hline
\end{tabular}
menghasilkan rendemen glukomanan yang semakin tinggi. Widyotomo dkk. (2004) menyatakan bahwa semakin kecilukuran mesh (ukuran partikel semakin besar) menunjukkan semakin banyak kandungan glukomanan. Penurunan kadar glukomanan diimbangidengan peningkatan kadar pati, kadar serat, dan derajat putih. Menurut Nasional (2011), menyatakan bahwa peningkatan kadar glukomanan diimbangi dengan semakin menurunnyakomponen-komponen nonglukomanan lainnya,sepertikadar lemak, kadar abu dan kadar pati. Afriani et al. (2013) menyatakan bahwa tiap partikel glukomanan mempunyai variasi ukuran yang berbeda, mulai dari $0.812-1.86 \mu \mathrm{m}$ atau $20-$ 200000 Dalton.

Komposisi kimia tepung glukomanan dengan ukuran berturut-turut yaitu 40, 60, 80, dan 100 mesh disajikan pada Tabel 1.

TABEL 1. HASIL ANALISIS KOMPOSISI KIMIA PADA BERBAGAI PENGAYAKAN (MESH)

\begin{tabular}{|c|c|c|c|c|c|}
\hline \multirow[t]{2}{*}{$\begin{array}{l}\text { Kompo } \\
\text { nen }\end{array}$} & \multicolumn{2}{|c|}{ partikel (mesh) } & \multicolumn{3}{|c|}{ Ukuran } \\
\hline & 40 & $40-60$ & $60-80$ & $\begin{array}{l}80- \\
100\end{array}$ & $<100$ \\
\hline $\begin{array}{l}\text { Gluko } \\
\text { manan } \\
(\%)\end{array}$ & $\begin{array}{r}6 . \\
67^{c}\end{array}$ & $\begin{array}{c}23.65 \\
\mathrm{a}\end{array}$ & $12.17^{\mathrm{b}}$ & $7.11^{\mathrm{c}}$ & $5.56^{\mathrm{c}}$ \\
\hline $\begin{array}{l}\text { Pati } \\
(\%)\end{array}$ & $\begin{array}{c}2 \\
2.43 \\
\mathrm{e}\end{array}$ & $\begin{array}{c}24.76 \\
\mathrm{~d}\end{array}$ & $27.86^{\mathrm{c}}$ & $29.63^{b}$ & $33.66^{\mathrm{a}}$ \\
\hline $\begin{array}{l}\text { Serat } \\
\text { kasar } \\
(\%)\end{array}$ & $\begin{array}{r}8 . \\
42^{\mathrm{ab}}\end{array}$ & $5.71^{\mathrm{b}}$ & $5.71^{\mathrm{b}}$ & $9.15^{\mathrm{ab}}$ & $14.57^{\mathrm{a}}$ \\
\hline Air (\%) & $\begin{array}{c}1 \\
1.19 \\
\mathrm{ab}\end{array}$ & $\begin{array}{c}11.40 \\
\mathrm{a}\end{array}$ & $\underset{c}{10.83^{b}}$ & $10.54^{\mathrm{c}}$ & $8.72^{\mathrm{d}}$ \\
\hline
\end{tabular}

Keterangan: Angka dengan huruf yang sama pada baris yang sama menunjukkan bahwa hasil uji Duncan tidak berbeda nyata secara signifikan

Tabel 1 menunjukkan bahwa perlakuan ukuran partikel berpengaruh nyata terhadap kadar glukomanan, pati, serat kasar, air, densitas kamba, viskositas, $\mathrm{pH}$, dan persentase bobot. Rendemen tertinggi terdapat pada tepung gadung ukuran 40-60 mesh, sedangkan kadar pati dan serat kasar tertinggiterdapatpadaukuran $<100$ mesh.Berdasarkan Tabel1danGambar1

pengecilanukurantepungcukupsampai40-

60mesh, diatasdandibawahukuran tersebut kandungan glukomanan rendah. Dari Tabel 1 tersebut berdasarkan analisis komposisi kimia didapatkan bahwa ukuran tersebut merupakan ukuran yang terbaik dalam ekstraksiglukomanan.

\section{Biaya Produksi}

Penetapan biaya produksi dilakukan dengan tujuan untuk mengetahui jumlah biaya yang diperlukan dalam menghasilkan produk chips kering, tepung gadung,danglukomanandaribahanbaku setiap 100kgumbisegar.Penetapan biaya tersebut mengacu pada neraca massa yang disajikan pada Gambar1.

Biaya produksi hanya mencakup biaya pembelian bahan baku, sumbangan biaya lain seperti etanol 96\%, aquades, solar, listrik untuk oven serta biaya pembuatan produk chips kering menjadi tepung gadung dan glukomanan. 
M F Kurnianto, Budi Hariono, Sri Hartatik. Neraca Massa, Komposisi Kimia Dan Nilai Ekonomis Pengolahan Agroindustri Glukomanan .

TABEL 2 PENETAPAN BiaYA PRODUKSI, NILAI TAMBAH, DAN KEUNTUNGAN BAHAN BAKU 100KG TERHADAP JENIS PRODUK SIAP JUAL PADA BERBAGAI PERLAKUAN

\begin{tabular}{|c|c|c|c|c|}
\hline No & $\begin{array}{l}\text { Bentuk } \\
\text { Produk }\end{array}$ & $\begin{array}{l}\text { Biaya } \\
\text { Prod. } \\
\text { (Rp/1 } \\
\text { 00kg) }\end{array}$ & $\begin{array}{c}\text { Nilai } \\
\text { Tambah } \\
(\mathrm{Rp} / 100 \\
\text { kg) }\end{array}$ & $\begin{array}{l}\text { Keuntung } \\
\text { an }(\%))\end{array}$ \\
\hline 1 & Umbi & $\begin{array}{l}350 \\
.000\end{array}$ & 0 & 0 \\
\hline 2 & Chips & $\begin{array}{l}400.0 \\
00\end{array}$ & 30.000 & 7,5 \\
\hline 3 & Tepung & $\begin{array}{l}450.0 \\
00\end{array}$ & 127.000 & 28,2 \\
\hline 4 & $\begin{array}{c}\text { Glukom } \\
\text { anan }\end{array}$ & $\begin{array}{l}750.0 \\
00\end{array}$ & 650.000 & 86,67 \\
\hline
\end{tabular}

Penetapan nilai tambah pada berbagai perlakuan dan jenis produk pada basis bobot $100 \mathrm{~kg}$ umbi basah menunjukkan bahwa setiap perlakuan pascapanen dan bentuk produk hasil pengolahan memberikan nilai tambah dan keuntungan yang berbeda-beda (Tabel 2). Berdasarkan Soekarto dan Adawiyah, 2010 bahwa nilai tambah produk diperoleh dari nilai produk dalam rupiah dikurangi dengan nilai input bahan baku dan nilai input lainnya sepertiongkos tenaga kerja proses dan bahan bakardalambasisperkg bahan baku, sedangkan keuntungan diperoleh dari nilai tambah dikurangi pembagian keuntungan dengan tenaga pengolahan. Persentase nilai tambah dan keuntungan pada tabel tersebut diperoleh dari fraksi nilai tambah dan keutungan terhadap output (pendapatan per kgproduk).

Berdasarkan Tabel 2, bahwa nilai tambah tertinggi diperoleh dari pengolahan menjadi glukomanan dengan nilai sebesar $\mathrm{Rp}$ $650.000 / 100 \mathrm{~kg}$, demikian pula dengan keuntungan sebesar 86,67 persen. Sedangkan nilai keuntungan terendah pada proses pengolahan umbi gadung menjadi chip kering.

Guna memilih proses yang lebih keuntungan, perlu diketahui sumber daya yangmenjadipembatas, apakahbahanbakunyaataumo dal (Adawiyah, 2010).Apabilayangmenjadi pembatas adalah bahan baku, maka dapat dipilih proses produksi glukomanan karenadenganjumlahbahanbakuyangsamadapatmem berikannilaitambahdan keuntungan yang lebih tinggi. Sebaliknya apabila yang menjadi pembatas adalah modal, maka proses yang dipilih adalah proses produksi tepung gadung karena akanmengurangibiayabahankimiaatausumbanganin putlainyangcukuptinggi.

\section{KESIMPULAN DAN SARAN}

Kesimpulan

1. Perhitungan neraca massa perlakuanperbedaanukuran mesh memberikan hasil yaitu semakin besar ukuran (ukuran partikel semakin kecil), menghasilkan glukomanan yang semakin sedikit. Fraksi tepung glukomanan yang lolos ayakan 40-60 mesh menghasilkan kandungan glukomanan paling tinggi dibandingkan dengan ukuran partikel yang lain.

2. Perlakuanukuranpartikelberpengaruhnyata terhadap kadar glukomanan, pati, serat kasar, air, densitas kamba, viskositas, $\mathrm{pH}$, dan persentase bobot. Rendemen tertinggi terdapat pada tepung gadung ukuran 40-60 mesh, sedangkan kadar pati dan serat kasar tertinggiterdapatpadaukuran $<100$ mesh.

3. Nilai tambah tertinggi diperoleh dari pengolahan menjadi glukomanan dengan nilai sebesar Rp 650.000/100kg, demikian pula dengan keuntungan sebesar 86,67 persen. Sedangkan nilai keuntungan terendah pada proses pengolahan umbi gadung menjadi chip kering.

\section{Saran}

Perlu dilakukan penelitian lanjutan keseragaman ketebalan irisan, pengontrolan waktu pengeringan untuk menghasilkan chips dengan kadar air yang tepat sehingga menghasilkan produk lebih seragam. Perlu dilakukan penelitian pengeringan dengan waktu pengamatan yang lebih pendek dan menggunakan umbi gadung dengan keseragam umur sehingga menghasilkan kadar air 
yang lebih seragam dan dilakukan analisis hubungan laju pengeringan dan fraksi air terikat dalam chip atau tepung gadung.

\section{DAFTAR PUSTAKA}

[1] Adawiyah DT \& Soekarto ST 2010. Pemodelan isotermis sorpsi air pada model pangan. Teknol dan Industri Pangan, 21 (1).

[2] Afriyani YD, Nirmala A, \& Aryanti N. 2013. Pemisahan konjak glukomanan menggunakan membran ultrafiltrasi. J Teknol Kimia dan Industri. 2 (4) : 164-169.

[3] AOAC. 2005. Official methods of analysis of the association official analitycal chemistry. Maryland: AOAC International Suite 500.

[4] Bo S, Muschin T, Kanamoto T, Nakashima H, Yoshida T. 2013. Sulfation and biological activities of konjac glucomannan. Carbohydr Polym. 94: 899903.

[5] Chua M, Chan K, Hocking TJ, Williams PA, Perry CJ, Baldwin TC. 2016. Methodologies for the extraction and analysis of konjac glucomannan

[6] Nasional, 2011-Teknologi Inovatif Pasca panen Pertanian. Bogor, Indonesia. 17 November 2011.

[7] Li B, Xie B, Keneedy JF. 2006. Studies on the molecular chain morphology of konjac glucomannan. Carbohydr Polym. 64: 510-515.

[8] Li J, Ji J, Xia J, Li B. 2012. Preparation of konjac glukomanan-based super absorbentpolymersbyfrontalpolymerization.Carbohy drPolym.87:757- 763.

[9] Liu TG, Wang Y, Xia J, Li B. 2017. Influence of purification method on the structure and properties of konjac glucomannan. Chem Forest Products. 25: 71-75.

[10]Raharjo BA ,Dewi NWS ,Haryani K. 2017. Pemanfaatan tepung glukomanan dari umbi umbi gadung (Amorphophallus oncophyllus) sebagai bahan baku pembuatan ediblefilm. JTeknologi Kimia dan Industri 1(1):401-411.

[11] Soekarto ST \& Adawiyah DR. 2010. Keterkaitan berbagai konsep interaksi air dalam produk pangan. $J$ Teknol Industri Pangan, 23 (1) :107-116.

[12]Widyotomo S,Purwadaria HK,Syarief AM ,SriMulato .2004.Distribusi partikel tepung iles produk pengecilan ukuran dengan metode pengolahan kering. Buletin Ilmia INSTIPER Vol. 11(1):51-7 
